\title{
Geographical tourism research and education at the Jagiellonian University School of Tourism in Poland (1936-1939)
}

\author{
Antoni Jackowski, Izabela Sołjan, Elżbieta Bilska-Wodecka, and Justyna Liro
}

Research Team on Geography of Religion, Institute of Geography and Spatial Management, Jagiellonian University, Gronostajowa 7, Krakow, Poland

Correspondence to: Justyna Liro (justyna.liro@uj.edu.pl)

Received: 5 October 2016 - Accepted: 2 November 2016 - Published: 17 November 2016

\begin{abstract}
The beginning of the twentieth century was a time of intensive development of geographical research on tourism, as well as the establishment of tourism research centers in many European countries. The Jagiellonian University School of Tourism played an important role in the development of tourism geography and education, spatial and regional planning, and personnel training for tourism developing in the 1930s in Poland. Tourism education in the school was characterized by a modern curriculum and forms of teaching, including fieldwork, focusing on developing practical skills, and linking research topics with the teaching process. The school conducted extensive research, publishing and documentary activities. The achievements of the Jagiellonian University School of Tourism helped raise awareness in society of the importance of tourism in the socio-economic development of regions and cities. This article presents the history of the Jagiellonian University School of Tourism and highlights its role in the development of tourism research and education in Europe. The school is mentioned among the pioneering centers of tourism, i.e., Robert Glucksmann's Tourism Research Institute at the Berlin School of Commerce, Walter Hunziker's and Kurt Krapf's tourism seminar in St. Gallen, and Raoul Blanchard's Institute of Alpine Geography in Grenoble.
\end{abstract}

\section{Introduction}

The article presents the history of the Jagiellonian University School of Tourism and its role in the development of geographical tourism research and education. The school was founded in 1936 and it was one of the first institutes of tourism geography. It conducted innovative academic courses using new research methods and results of studies. It also discussed publishing and popularizing the activities of the school. Particular attention was paid to cooperation with tourist organizations and similar research centers all over the world. The article also presents the school in relation to the development of tourism research centers in Europe. The school's history has been researched only partially in Polish (Jackowski, 2003; Leszczycki, 1992; Tokarski, 1992; Jackowski and Sołjan, 2009; Jackowski and Liro, 2015). The first published information about the Jagiellonian University School of Tourism appeared shortly after its founding (Kli- maszewski, 1936; Nawratilówna, 1938). Due to the lack of source materials and archives, which were lost during World War II, the study was mainly based on published reports and the information contained in pre-war publications and journals (Leszczycki, 1937, 1938). Archival materials belonging to Antoni Jackowski, provided to him by the school's founder Stanisław Leszczycki, were also used.

\section{The development of tourism geography in Europe until 1939}

Along with the appearance in Europe, at the turn of the eighteenth and nineteenth centuries, of a growing number of people travelling for pleasure, representatives of many scientific disciplines became interested in this phenomenon. Among the first ones who paid attention to this issue were geographers. In addition to naturalists and humanists, they made an important contribution to the development of scientific 
research on tourism. It was a time when the issues of geographical research began to move away from studies limited almost exclusively to the natural environment, and research into various aspects of human activity was undertaken. Geographers also developed tourist guides to help travellers visit the most interesting places. The issues of broadly understood tourism were firstly addressed by geographers from Germany and Austria. Alexander von Humboldt should be primarily included among these scientists. Humboldt's work is characterized by the connected elements of nature and ethnography, as well as man's economic activity, modern at that time. The knowledge of tourism was to a considerable extent taken into account by Karl Ritter, the founder of modern geography (Ritter, 1822-1859). He preferred the regional presentation of geographical phenomena. The issues associated with tourism were also noticed by Friedrich Ratzel, one of the developers of anthropogeography. His works contain information related to ethnography and tourist values (Ratzel, 1882). A settlement network that developed as a result of tourist visits was described by Johann Georg Kohl (1841). Similar issues were broadly taken into account by Alfred Hettner, Kurt Hassert, and Josef Stradner. Alfred Hettner (1927), a prominent theorist of geography, devoted much attention in his significant work to tourist destinations and health resorts, as well as to the already emerging process of excessive urbanization. Similarly, Kurt Hassert mentions places where development was linked to tourist functions (Hasser, 1908). Josef Stadner was the first to present a study of scientific issues related to tourism and the research scope of tourism geography (Stadner, 1905). Josef Stadner, geographer and ethnographer, an explorer of the region of the Adriatic Sea, was the first to attempt to outline the research scope of tourism geography (Fremdenvekrehrsgeographie), and discussed the impact of tourism on the development of the national economy, the issue of tourist values, land development and accessibility in terms of communication. At that time, two series of research expeditions called the International Polar Year (IPY) had a large impact on the development of geographical research and spotting its multidisciplinarity. The first Polar Year took place in the years 18821883 , and the second one in 1932-1933. The studies of polar regions undertaken by an international team of experts included observations in all fields of Earth science, and set off their development.

Geographers began to notice and explain the spatial aspects of travelling, tourism, and recreation in the 1920s (Mitchell and Murphy, 1991). The 1930s were a period of intensive development of geographical studies on tourism. The scope of research in this field began to systematize more and more strongly. The development of spatial planning in Europe and North America caused the issue of tourism to be increasingly taken into account in planning studies. The development of tourism meant that academic institutions specializing in tourism research and education started to be established in a number of countries. This took place especially in those countries where tourism played an important role in the socio-economic policy, i.e., Germany, Switzerland, Italy, and the UK. Between 1929 and 1934, the primary unit was the Berlin School of Tourism Research (Forschungsinstitut für den Fremdenverkehr) at the Berlin School of Commerce (Handelschochule, and since 1935 Wirtschaftshochsule). The head of this institution was Robert Glücksmann, one of the leading theorists of sociology and tourism geography (Panosso Nettoa and Jäger, 2015). The most prominent geographers associated with the Berlin School of Tourism Research were Georg Wegener (1929) and Adolf Grünthal (1934). An important role in these studies was played by the Institutes of Geography in Innsbruck and Vienna. Hans Poser is considered to be one of the most important developers of tourism geography. His work was the first monograph on tourism in the Karkonosze Mountains (Poser, 1939).

The issues of tourism also began to appear in French geographical literature, mainly owing to Paul Vidal de la Blache, widely recognized as the pioneer in geography in France, and also one of the co-founders of European anthropogeography. He was the author of numerous works of a regional nature (Vidal de la Blache, 1922). His work in this field - "Principes de géographie humaine" (published posthumously in 1922 by Emanuel de Martonne) - has been republished up to the present day. Pierre Lasserre introduced to the literature of the subject the term "industrie touristique", a concept that was later to become synonymous with the tourist economy (Lasserre, 1930). A leading research center was the Institute of Alpine Geography in Grenoble (Institut de Géographie Alpine), founded in 1907 by Raoul Blanchard (1911, $1919,1925,1928)$. Geographers involved in tourism were able to publish in the journal "Revue de Géographie Alpine" founded by Raoul Blanchard in 1913. The journal is still published today. Moreover, research in this field was conducted in France by geographers affiliated with the universities in Toulouse, Bordeaux and Pau. Thus, tourism geography in France became one of the most applicable disciplines of geography. In 1941 in Switzerland, Walter Hunziker and Kurt Krapf established in St. Gallen a research center on tourism (Seminar für Fremdenverkehr). In Italy, geographical conditions for the development of tourism were dealt with by Angelo Mariotti, a professor at the Sapienza University in Rome (Mariotti, 1933, 1939). Among the British works, the studies by Frederick Wolff Ogilvie and Arthur Norval are noteworthy. Frederick Wolff Ogilvie's (1933) work about the economic aspects of tourism is considered to be the first monograph in the UK in the field of the sociology of tourism. He attributed considerable importance to the geographical conditions for the development of tourism. Arthur Norval's (1936) work concerns the tourism industry, in which an interesting part refers to natural tourist attractions, mainly in South Africa.

The traditions of tourism studies in Poland are associated primarily with the Jagiellonian University (Jackowski, 2010). 


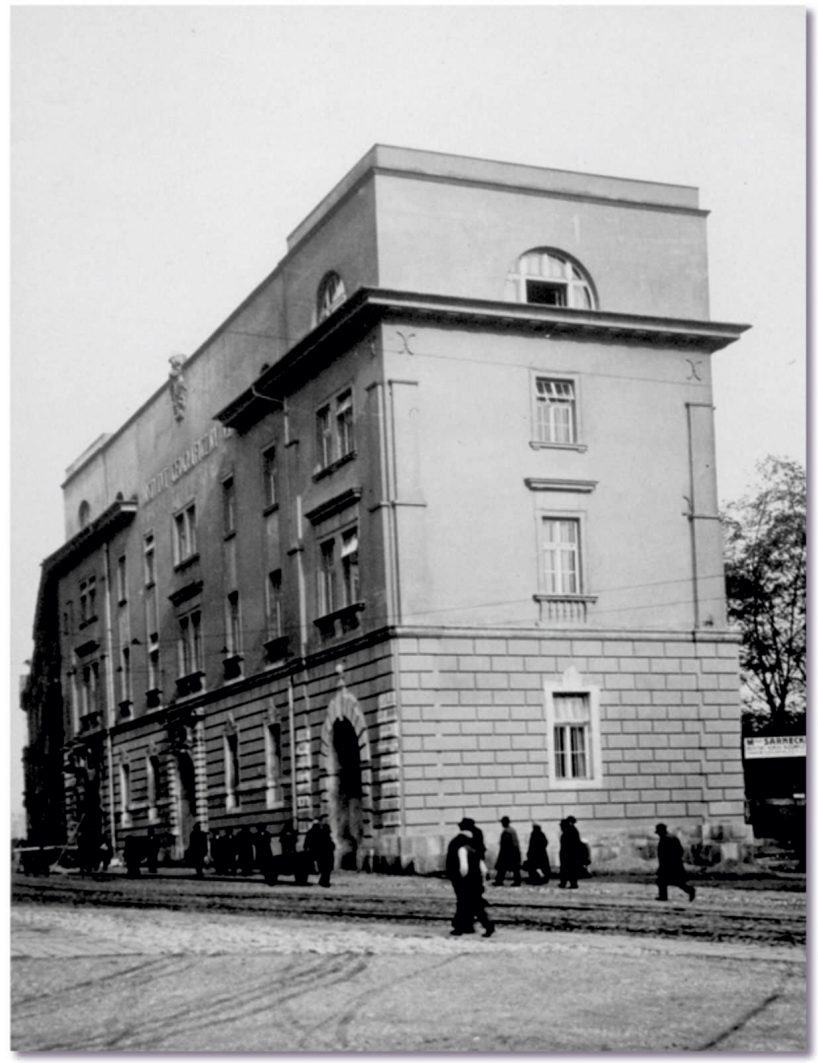

Figure 1. The building of the Jagiellonian University School of Tourism in 1936, Krakow (source: the archives of Antoni Jackowski).

The inter-war period was characterized by high tourist activity of Polish society. In 1938, about 3 million people took part in tourist trips. The number of holiday resorts increased from about 300 in the early 1920s to over 1000 just before World War II. The growing importance of tourism, and the economic and spatial processes related to it, were also recognized by geographers as early as before World War I. Compared to the European countries and the US, tourism geography began to develop in Poland relatively late, only after 1930. On 14-18 May 1935, a session of Conseil Central de Tourisme International, the most important international tourist organization at that time, was held in Krakow in Poland.

The decision to found the Jagiellonian University School of Tourism in the 1930s was influenced among others by the development of tourism, spatial and regional planning, and the growing interest in tourism on the part of government authorities and business organizations.

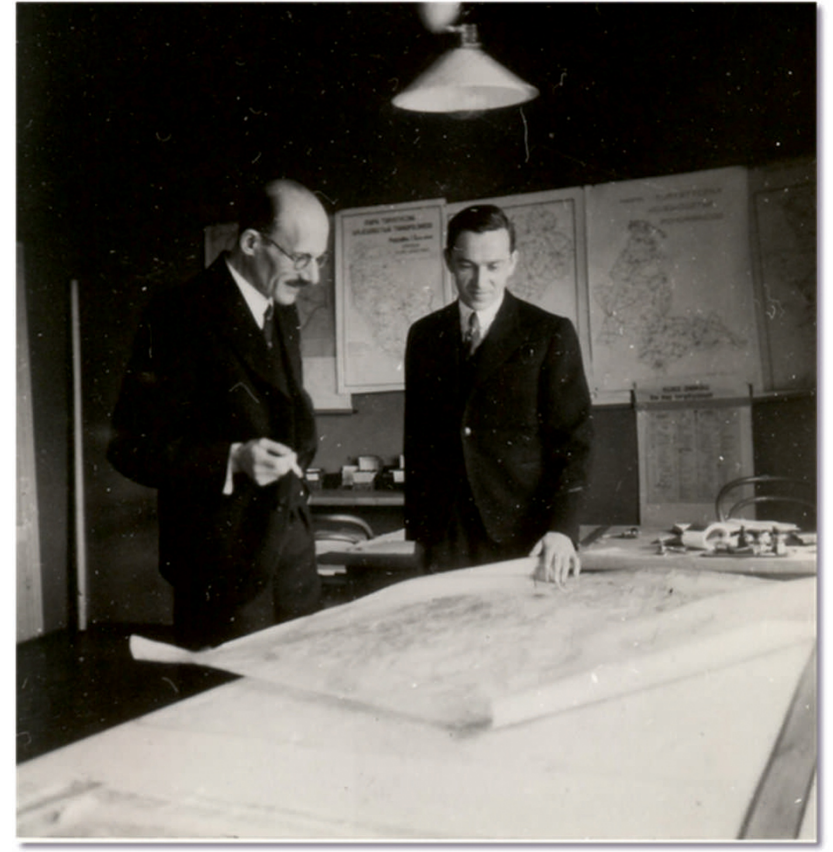

Figure 2. Stanislaw Leszczycki, head of the school, with Jerzy Smolenski during a seminar, 1936 (source: the archives of Antoni Jackowski).

\section{The foundation and activity of the Jagiellonian University School of Tourism}

The Provincial Office in Krakow decided to establish a research unit at the Jagiellonian University, inspired by and based on similar institutes in some foreign universities, especially the Berlin Tourism School of Research. The Provincial Office was a government organization concerned with spatial planning and development of the Lesser Poland Province. Krakow, the heart of the most important tourism region, was chosen as the center of studies on tourism in Poland. The selection of this location was also supported by the fact that the top Polish geographers who were interested in the issues of tourism worked there (Fig. 1).

The Jagiellonian University School was established on 23 April 1936 at the Jagiellonian University in Krakow. Founded in 1364, the Jagiellonian University is the oldest university in Poland, and the second oldest university in central Europe. The school was headed by Stanisław Leszczycki (Fig. 2). The main purpose of its activities was to scientifically research tourism and to train staff for tourism institutions. The unit was funded by regional tourist organizations and the local government commissioning tasks from it, as well as by the Ministry of Communications and the League for the Promotion of Tourism in Poland. 
Table 1. Tourism education at the Jagiellonian University School of Tourism (source: authors' own work based on archival materials of the school).

\begin{tabular}{|c|c|c|}
\hline $\begin{array}{l}\text { Academic } \\
\text { year }\end{array}$ & Course & Course type \\
\hline $1935 / 1936$ & $\begin{array}{l}\text { Geographical and economic basics of aspects of tourism } \\
\text { Tourism geography }\end{array}$ & $\begin{array}{l}\text { Lectures } \\
\text { Seminars and fieldwork }\end{array}$ \\
\hline $1936 / 1937$ & $\begin{array}{l}\text { The basics of tourism geography } \\
\text { Statistics and applied cartography } \\
\text { Tourism geography of Poland } \\
\text { Statistics and applied cartography } \\
\text { The health resorts of Europe } \\
\text { Balneography }\end{array}$ & $\begin{array}{l}\text { Lectures, seminars and practicums } \\
\text { Seminars, practicums, excursions and fieldwork } \\
\text { Lectures, discussions, excursions and fieldwork } \\
\text { Seminars, practicums, excursions and fieldwork } \\
\text { Discussions, seminars, excursions, and summer internships } \\
\text { Lectures and discussions }\end{array}$ \\
\hline $1937 / 1938$ & $\begin{array}{l}\text { Tourism geography } \\
\text { Statistics and applied cartography } \\
\text { Geographical basics of regional planning } \\
\text { Balneography } \\
\text { The balneography of Poland and Europe }\end{array}$ & $\begin{array}{l}\text { Lectures and seminars } \\
\text { Seminars, practicums, excursions and fieldwork } \\
\text { Lectures, seminars and summer internships } \\
\text { Lectures and discussions } \\
\text { Lectures and discussions }\end{array}$ \\
\hline $1938 / 1939$ & $\begin{array}{l}\text { Tourism geography } \\
\text { Tourism geography of Poland } \\
\text { Balneography } \\
\text { The issues of tourism in Europe }\end{array}$ & $\begin{array}{l}\text { Lectures, discussions and seminars } \\
\text { Lectures, discussions, excursions, and fieldwork } \\
\text { Lectures and discussions } \\
\text { Lectures and seminars }\end{array}$ \\
\hline
\end{tabular}

\subsection{Tourism education}

One of the main tasks of the school was to train people who were to work in tourist institutes in the future. Students graduating from the Jagiellonian University Faculties of Philosophy and Law, and the School of Physical Education, were admitted to a 1-year course in the Jagiellonian University School of Tourism. In the academic year 1936/1937, the school had 20 students and, in 1937/1938 and 1938/1939, 22. The students included a number of people who later played an important role in Polish geography, tourism, environmental protection, and spatial planning.

The main teaching forms included lectures, discussions, seminars, practicums, excursions, fieldwork, and summer internships (Table 1).

Scholl's students were required to prepare seminar papers covering a very broad scope of problems. They related to the issues of nature conservation in the context of the development of tourist phenomena, European winter sports stations and health resorts, tourist attractions, various forms of tourism, tourism development, transport accessibility, tourism statistics, legal and organizational issues, and the history of tourism. Summer internships were held mainly at the offices of the League for the Promotion of Tourism, among others, in Gdynia, Krynica, Szczawnica, Zakopane, Lvov, Warsaw, and Vilnius. Such internships were also carried out in departments of the Polish Tourist Association in Krakow, the Holiday Association of the Districts and Municipalities of the Province of Krakow, the Association of the Propagation of Tourism of the Capital City of
Warsaw, and in the Union of Chambers of Commerce and Industry. Some students went for international internships, among others in Denmark, Greece, Yugoslavia, and Italy. During the academic year, five to seven excursions mainly to the Carpathian Mountains and to the north of Poland, and Latvia, Estonia, Finland, Norway, and Sweden were held. The Jagiellonian University School of Tourism also organized training workshops for employees of local government institutions and tourism organizations. Measures were taken to introduce classes in tourism (as a subject of instruction) into vocational secondary education. It also voiced its opinion on the curricula provided for hotel training schools.

\subsection{Scientific and documentary activities}

Scientific activity was the second main purpose of the Jagiellonian University School of Tourism. Basic material was collected during fieldwork. The school gathered supporting materials, mainly in the form of files of tourist attractions, and a cadaster of holiday resorts. The result of its research activity was over 100 study works, many of which were recognized as theses, including master's theses at the Jagiellonian University Institute of Geography. The research issues were very extensive. Studies of the Carpathian Mountains, issues of tourism and health resorts relating to the whole of Poland and other countries, especially Germany, clearly dominated among the published works. The most important research issues focused on the theory of tourism geography, statistics and classifications, tourist movement and industry, regional planning and tourism policy (Table 2). 
Table 2. Research issues of the Jagiellonian University School of Tourism (source: authors' own work based on archival materials of the school).

\begin{tabular}{|c|c|}
\hline Research issues & Examples \\
\hline Definition and scope of tourism geography & $\begin{array}{l}\text { Method of point grading in tourism } \\
\text { Basis for regional planning studies for tourism }\end{array}$ \\
\hline Statistics and classification & $\begin{array}{l}\text { Tourist regionalization of Poland } \\
\text { Classification of tourist attractions and health resorts in the Carpathians } \\
\text { Classification of tourist development in the Carpathians } \\
\text { Database of tourist destinations in Poland and in the mountain areas of Europe }\end{array}$ \\
\hline Tourist movement & $\begin{array}{l}\text { Tourist movement in Albania, Austria, Belgium, Finland, Germany, Romania, and Sweden } \\
\text { International tourist movement in Poland and Europe } \\
\text { Seasonality of the tourism movement in the Carpathians, Poland and Europe } \\
\text { Tourism in health resorts in Poland and Europe } \\
\text { Ski tourism in Poland and Europe and in the world }\end{array}$ \\
\hline Tourist industry & $\begin{array}{l}\text { Impact of tourism on the local economy } \\
\text { Classification of tourist resorts due to economic factors } \\
\text { Economic importance of the tourist movement in Silesia, the Carpathians and Poland } \\
\text { Hotel industry in Poland and Europe }\end{array}$ \\
\hline $\begin{array}{l}\text { Economic importance } \\
\text { of nature reserves }\end{array}$ & $\begin{array}{l}\text { Landscape protection in tourism and health resorts in Poland and Europe } \\
\text { Importance of nature reserves for tourism development }\end{array}$ \\
\hline $\begin{array}{l}\text { Regional planning } \\
\text { and tourism policy }\end{array}$ & $\begin{array}{l}\text { Development strategy of tourism in the Carpathians, Malopolska and Silesia } \\
\text { Development strategy of tourism and health resorts in Poland } \\
\text { Tourist business agreements and laws for summer resorts and health resorts in Poland } \\
\text { Tourism policy in Germany, Italy and Switzerland }\end{array}$ \\
\hline
\end{tabular}

However, it was theoretical treatises that proved to be of essential importance in the development of tourism geography as an independent discipline of geographical sciences. Stanisław Leszczycki (1938) defined tourism geography in the following way:

Tourism geography is the whole of theoretical, economic, cultural, geographical, statistical, legal, cultural, and social issues related to the tourist movement. The main issues of tourism geography are related to man, the geographical environment, economic exploitation of the ground, and the works and culture of man.

This was a clear improvement over previous attempts, which often narrowed tourism geography to the examination of only selected issues related to tourism, mainly of the natural environment. The school sought to develop a research methodology for tourist phenomena. It was in the works of this institution that the method of point grading which was applied to the classification of tourist attractions and tourist development of towns and villages in Podhale (mountain region in Poland) was first used. This method began to be used almost universally only in the post-war studies in Poland, especially until the mid-1970s.

The issue of tourist destinations occupied an important place in the studies of the school. Works on the cadaster of resorts were aimed at developing a uniform method of registering tourist events and the attendance and tourist development in Poland.

For example, Stanisław Leszczycki presented the following classification scheme for health resorts.

1. Large companies (holdings with the resort tax or with public utilities). These include health resorts, climate stations (high montane, montane, submontane, village, forest, steppe), and bathing resorts (sea, river, lake).

2. Qualified companies - including health resorts, bathing resorts without the right to levy the resort tax, large developed summer resorts (entertainment destinations), and equipped individual structures (hotels, hostels, guest houses, mansions).

3. Non-qualified companies - including small, nonequipped summer resorts, villages, towns, nonequipped individual structures (mansions, guest houses, shelters, foresters' lodges, presbyteries), camps and colonies. The distinguishing feature of studies developed in the school was widely taking into account economic issues. Stanislaw Leszczycki, as the first in Poland, took into consideration the issue of the socalled "holiday traffic", which is now called "weekend tourism". He also pointed to the relationship between 


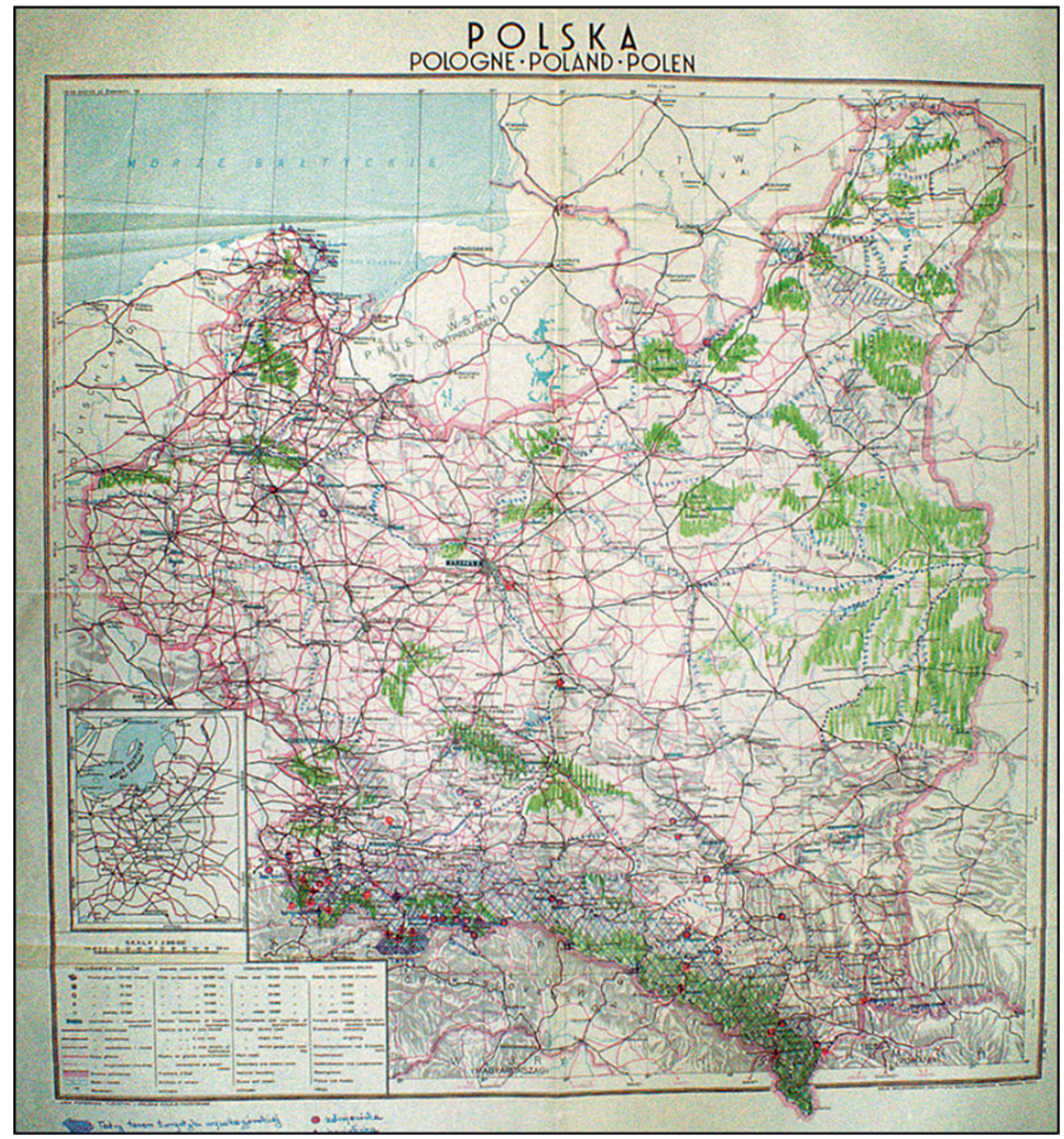

Figure 3. Map of tourist attractions in Poland. Author: Stanisław Leszczycki, handmade (source: the archives of Antoni Jackowski).

the tourist activity of inhabitants and the level of income, and presented the financial gains achieved by each town or village receiving tourists in Poland.

The Jagiellonian University School of Tourism also had its major achievements in the field of tourist cartography. At the end of 1938, the archive had over 100 manuscript maps deal- ing with various issues related to tourism. Undoubtedly, the biggest project involved the works on the Tourist Atlas of Poland (Fig. 3). By the end of 1938, 21 maps for the general section (a scale of $1: 1000000$ ) and 17 tourist maps of provinces and the capital city of Warsaw for the specific section (a scale of $1: 100000$ ) were developed. In 1939, all the 
studies were basically completed; however, most of them disappeared during World War II.

Among the school's activities in the cartographic fieldwork on a tourist map of Poland at a scale of 1:50 000, a map of holiday resorts and winter holiday resorts in Europe and a map of car and tourist roads in mountainous areas of Europe can be mentioned. Moreover, at the turn of 1938/1939, works on the development of the geography of international tourism in Europe were begun. A distinguishing feature of the study conducted by the Jagiellonian University School of Tourism was also its extensive consideration of economic issues. The school also conducted documentary activity. It mainly involved works on the "file of tourist attractions", a register of individual tourist attractions and infrastructure. At the end of 1938, the file had a record of approx. 17000 attractions in Poland, and nearly 2200 literature items.

\subsection{Publishing activity}

The school conducted extensive publishing activity, issuing Prace Studium Turyzmu UJ (The Papers of the Jagiellonian University School of Tourism) (6 volumes), Komunikaty Studium Turyzmu UJ (Announcements of the Jagiellonian University School of Tourism) (22 volumes), and the Turyzm Polski (Tourism of Poland) journal (annual volumes 19381939). Original treatises approaching research topics in a comprehensive manner were published in "The Papers of the Jagiellonian University School of Tourism", whereas summaries of the conducted works, reports, statements, preliminary test results, statistical materials and translations were published in the "Announcements of the Jagiellonian University School of Tourism". Theoretical problems and organizational and economic issues of tourism, as well as statistical publications, chronicles of events in tourism both in the country and worldwide, as well as a review of the literature on tourism occupied the principal place in the Turyzm Polski journal.

The publications of the school tried to take the most important and most current topics for the development of tourism, often in relation to economic issues. Also, numerous foreign authors presented their papers there, among others Karin Dieckmann (Finland), Nicolas D. Eghinitis (Greece), Maximilian Klafkowski (Germany), Angelo Mariotti (Italy), and Ksarlis Vanags (Lithuania) (Table 3).

\subsection{International cooperation}

The Jagiellonian University School of Tourism established contacts with similar foreign institutions, public agencies, local governments, and others related to tourism in Europe. The main objectives of cooperation in research were exchanging scientific and statistical materials, and organizing field studies for the participants. The first direct contacts were established with institutions in Austria, Greece, Yugoslavia, Germany, Romania, and Italy. The school entered into relation- ships with nearly 50 European partners. Moreover, contacts with official tourist offices of all European countries, and many countries outside Europe, as well as with international organizations related to tourism, were maintained. An important role in the development of this cooperation was played by the Tourism of Poland journal (an exchange with 72 periodic publications from 28 countries in 1938). Additionally, the Jagiellonian University School of Tourism developed the following expert opinions:

- the organization of tourism in Poland for the French Tourist Office (Office National du Tourisme);

- the organization of tourism in Poland for the International Labor Office in Geneva; and

- the economic issues of international tourism for Conseil Central du Tourisme International.

\section{Conclusion}

As a result of financial problems and a conflict regarding nature conservation, the Jagiellonian University School of Tourism had to suspend its activities in 1939. The ultimate end came with the outbreak of World War II and the arrest of the head of the school, Stanisław Leszczycki, as part of Sonderaktion Krakau.

This article presents the history of the Jagiellonian University School of Tourism. The school played an important role in the development of tourism geography and education in Europe, especially in Poland. The curriculum and teaching methods, both indoors and in the field, were modern at that time, and are still in practice. A very strong link between research studies and the teaching process should be emphasized. Owing to this, tourist facilities were manned by a well-prepared staff of specialists, a large group of whom constituted the basis of the staff employed in tourism, spatial planning, and research centers. A very strong link between research studies and the teaching process should be emphasized. Attention should also be paid to the practical aspect of most of the studies commissioned by various agencies, institutions, and organizations. Students were engaged to carry out the school's research program, which resulted in the integration of the team, in the further participation of graduates in study works, and in the organization of field studies. Systematic studies in this field began to be conducted for the first time in Poland. The issues addressed in research work were related to a wide variety of topics. The school also sought to develop the terminology and methodology of the study of tourism. The method of point grading, which was applied to the classification of tourist attractions, was first used in the school. Great importance was also attached to the study of issues related to the classification of tourist destinations on the basis of the size of tourist movement and the transformation of the physiognomy of villages and towns under the influence of tourism. The Jagiellonian University School of 
Table 3. The selected articles published by the Jagiellonian University School of Tourism (source: authors' own work based on archival materials of the school).

\begin{tabular}{|c|c|c|c|c|}
\hline Year & Author & Original title & English title & Journal \\
\hline 1932 & $\begin{array}{l}\text { Stanisław } \\
\text { Leszczycki } \\
\text { turystyki }\end{array}$ & $\begin{array}{l}\text { Geografia turystyczna jako } \\
\text { naukowe ujęcie zagadnień }\end{array}$ & $\begin{array}{l}\text { Tourism geography } \\
\text { as a scientific approach } \\
\text { Balneologicznego }\end{array}$ & $\begin{array}{l}\text { Pamiętnik Polskiego } \\
\text { Towarzystwa }\end{array}$ \\
\hline \multirow[t]{2}{*}{1934} & \multirow[t]{2}{*}{$\begin{array}{l}\text { Stanisław } \\
\text { Leszczycki }\end{array}$} & $\begin{array}{l}\text { Plany regulacyjne i ochrona } \\
\text { krajobrazu w uzdrowiskach } \\
\text { oraz gminach posiadających } \\
\text { walory krajobrazowe }\end{array}$ & $\begin{array}{l}\text { Plans and landscape } \\
\text { protection in health } \\
\text { resorts and towns with } \\
\text { landscape values }\end{array}$ & $\begin{array}{l}\text { Komunikaty Komisji } \\
\text { Regionalnej Podhala } \\
\text { i Beskidów Zachodnich }\end{array}$ \\
\hline & & $\begin{array}{l}\text { Les regions de l'industrie } \\
\text { balneaire et touristique en } \\
\text { Pologne }\end{array}$ & $\begin{array}{l}\text { The regions of the } \\
\text { seaside and tourism } \\
\text { industry in Poland }\end{array}$ & Acta Balneologica \\
\hline \multirow[t]{5}{*}{1937} & \multirow[t]{5}{*}{$\begin{array}{l}\text { Stanisław } \\
\text { Leszczycki }\end{array}$} & $\begin{array}{l}\text { Podhale jako region } \\
\text { turystyczny }\end{array}$ & $\begin{array}{l}\text { Podhale as a tourist } \\
\text { region }\end{array}$ & $\begin{array}{l}\text { Prace Studium Turyzmu } \\
\text { UJ }\end{array}$ \\
\hline & & $\begin{array}{l}\text { Region Podhala. Podstawy } \\
\text { geograficzno-gospodarcze } \\
\text { planu regionalnego }\end{array}$ & $\begin{array}{l}\text { Podhale region. The } \\
\text { basics of the geographic } \\
\text { and economic regional } \\
\text { plan }\end{array}$ & $\begin{array}{l}\text { Biuletyn Komisji } \\
\text { Studiów Ligii Popierania } \\
\text { Turystyki }\end{array}$ \\
\hline & & $\begin{array}{l}\text { Współczesne zagadnienia } \\
\text { geografii turyzmu }\end{array}$ & $\begin{array}{l}\text { Contemporary issues } \\
\text { of tourism geography }\end{array}$ & $\begin{array}{l}\text { Komunikaty Studium } \\
\text { Turyzmu UJ }\end{array}$ \\
\hline & & Zagadnienia geografii turyzmu & $\begin{array}{l}\text { The issues of tourism } \\
\text { geography }\end{array}$ & $\begin{array}{l}\text { Komunikaty Studium } \\
\text { Turyzmu UJ }\end{array}$ \\
\hline & & $\begin{array}{l}\text { Znaczenie gospodarcze ruchu } \\
\text { uzdrowiskowo-turystycznego } \\
\text { na Śląsku }\end{array}$ & $\begin{array}{l}\text { The economic } \\
\text { importance of the tourist } \\
\text { movement in Silesia }\end{array}$ & $\begin{array}{l}\text { Zagadnienia } \\
\text { Gospodarcze Śląska }\end{array}$ \\
\hline \multirow[t]{7}{*}{1938} & $\begin{array}{l}\text { Karin } \\
\text { Dieckmann }\end{array}$ & $\begin{array}{l}\text { Die organisation des } \\
\text { fremdenverkehrs in Finnland }\end{array}$ & $\begin{array}{l}\text { The organization of the } \\
\text { international tourist } \\
\text { movement in Finland }\end{array}$ & Tourism of Poland \\
\hline & $\begin{array}{l}\text { Nicolas } \\
\text { Eghinitis }\end{array}$ & $\begin{array}{l}\text { De moyenes modernes } \\
\text { de la propagande touristique }\end{array}$ & $\begin{array}{l}\text { Modern means of tourist } \\
\text { propaganda }\end{array}$ & Tourism of Poland \\
\hline & $\begin{array}{l}\text { Nicolas } \\
\text { Eghinitis }\end{array}$ & $\begin{array}{l}\text { Les qualites touristiques de la } \\
\text { Grece }\end{array}$ & $\begin{array}{l}\text { Tourist qualities } \\
\text { of Greece }\end{array}$ & Tourism of Poland \\
\hline & $\begin{array}{l}\text { Walery } \\
\text { Goetel }\end{array}$ & Turystyka a ochrona przyrody & $\begin{array}{l}\text { Tourism and nature } \\
\text { conservation }\end{array}$ & Tourism of Poland \\
\hline & \multirow{3}{*}{$\begin{array}{l}\text { Stanisław } \\
\text { Leszczycki }\end{array}$} & $\begin{array}{l}\text { Ruch uzdrowiskowo- } \\
\text { letniskowy w Polsce }\end{array}$ & $\begin{array}{l}\text { The tourist movement } \\
\text { in Poland }\end{array}$ & $\begin{array}{l}\text { Komunikaty Studium } \\
\text { Turyzmu UJ }\end{array}$ \\
\hline & & $\begin{array}{l}\text { Uzdrowiska Polski i ich } \\
\text { rozmieszczenie oraz rozwój } \\
\text { w latach 1922-1938 }\end{array}$ & $\begin{array}{l}\text { The Polish health resorts } \\
\text { and their distribution and } \\
\text { development in the years } \\
\text { 1922-1938 }\end{array}$ & $\begin{array}{l}\text { Komunikaty Studium } \\
\text { Turyzmu UJ }\end{array}$ \\
\hline & & $\begin{array}{l}\text { Wytyczne gospodarki } \\
\text { uzdrowiskowo-letniskowej } \\
\text { w Karpatach }\end{array}$ & $\begin{array}{l}\text { Guidelines for the } \\
\text { summer resort in the } \\
\text { Carpathian Mountains }\end{array}$ & $\begin{array}{l}\text { Komunikaty Studium } \\
\text { Turyzmu UJ }\end{array}$ \\
\hline
\end{tabular}


Table 3. Continued.

\begin{tabular}{|c|c|c|c|c|}
\hline Year & Author & Original title & English title & Journal \\
\hline \multirow[t]{11}{*}{1938} & $\begin{array}{l}\text { Elfryda } \\
\text { Trybowska }\end{array}$ & $\begin{array}{l}\text { Organizacja ruchu } \\
\text { turystycznego w Niemczech }\end{array}$ & $\begin{array}{l}\text { The organization of } \\
\text { tourism in Germany }\end{array}$ & Tourism of Poland \\
\hline & $\begin{array}{l}\text { Mieczysław } \\
\text { Orłowicz }\end{array}$ & $\begin{array}{l}\text { Statystyka turystyczna w } \\
\text { Austrii }\end{array}$ & $\begin{array}{l}\text { Tourist statistics in } \\
\text { Austria }\end{array}$ & Tourism of Poland \\
\hline & $\begin{array}{l}\text { Zbigniew } \\
\text { Tokarski }\end{array}$ & $\begin{array}{l}\text { Podstawy prawne turystyki } \\
\text { w Rumunii }\end{array}$ & $\begin{array}{l}\text { The legal basis for } \\
\text { tourism in Romania }\end{array}$ & Tourism of Poland \\
\hline & $\begin{array}{l}\text { Zbigniew } \\
\text { Tokarski }\end{array}$ & $\begin{array}{l}\text { Zagospodarowanie } \\
\text { turystyczne Karpat. } \\
\text { Rozmieszczenie i typy } \\
\text { schronisk }\end{array}$ & $\begin{array}{l}\text { The tourist facilities } \\
\text { of the Carpathians. } \\
\text { Distribution and types } \\
\text { of resorts }\end{array}$ & Tourism of Poland \\
\hline & $\begin{array}{l}\text { Elfryda } \\
\text { Trybowska }\end{array}$ & $\begin{array}{l}\text { Geograficzne rozmieszczenie } \\
\text { narciarstwa na świecie }\end{array}$ & $\begin{array}{l}\text { The geographical } \\
\text { distribution of skiing } \\
\text { in the world }\end{array}$ & Tourism of Poland \\
\hline & $\begin{array}{l}\text { Czesław } \\
\text { Trybowski }\end{array}$ & $\begin{array}{l}\text { Normy klimatyczne } \\
\text { miejscowości } \\
\text { uzdrowiskowych } \\
\text { w Niemczech }\end{array}$ & $\begin{array}{l}\text { The climatic standards } \\
\text { of the health resorts } \\
\text { in Germany }\end{array}$ & Tourism of Poland \\
\hline & $\begin{array}{l}\text { Tadeusz } \\
\text { Wilgat }\end{array}$ & $\begin{array}{l}\text { Rozmieszczenie przemysłu } \\
\text { hotelowego w Polsce }\end{array}$ & $\begin{array}{l}\text { Distribution of the hotel } \\
\text { industry in Poland }\end{array}$ & Tourism of Poland \\
\hline & & $\begin{array}{l}\text { Ruch cudzoziemców } \\
\text { w Finlandii }\end{array}$ & $\begin{array}{l}\text { The international tourist } \\
\text { movement in Finland }\end{array}$ & Tourism of Poland \\
\hline & & $\begin{array}{l}\text { Ruch cudzoziemców } \\
\text { w Rumunii }\end{array}$ & $\begin{array}{l}\text { The international tourist } \\
\text { movement in Romania }\end{array}$ & Tourism of Poland \\
\hline & & $\begin{array}{l}\text { Ruch cudzoziemców } \\
\text { w Szwecji }\end{array}$ & $\begin{array}{l}\text { The international tourist } \\
\text { movement in Sweden }\end{array}$ & Tourism of Poland \\
\hline & & Turystyka w Belgii & Tourism in Belgium & Tourism of Poland \\
\hline \multirow[t]{5}{*}{1939} & $\begin{array}{l}\text { Wanda } \\
\text { Leszczycka }\end{array}$ & $\begin{array}{l}\text { Ruch uzdrowiskowo- } \\
\text { letniskowy w } \\
\text { województwie pomorskim } \\
\text { w sezonie letnim } 1938\end{array}$ & $\begin{array}{l}\text { The tourist movement in } \\
\text { the Pomeranian province } \\
\text { in the summer season of } \\
1938\end{array}$ & $\begin{array}{l}\text { Komunikaty Studium } \\
\text { Turyzmu UJ }\end{array}$ \\
\hline & $\begin{array}{l}\text { Tadeusz } \\
\text { Chorabik }\end{array}$ & $\begin{array}{l}\text { Sezon letni w ruchu } \\
\text { uzdrowiskowo-turystycznym } \\
\text { w województwie krakowskim }\end{array}$ & $\begin{array}{l}\text { The summer season } \\
\text { of the tourist movement } \\
\text { in the region of Krakow }\end{array}$ & $\begin{array}{l}\text { Komunikaty Studium } \\
\text { Turyzmu UJ }\end{array}$ \\
\hline & $\begin{array}{l}\text { Mieczysław } \\
\text { Fularski }\end{array}$ & $\begin{array}{l}\text { Aktualne problemy turystyki } \\
\text { zagranicznej }\end{array}$ & $\begin{array}{l}\text { The current problems } \\
\text { of international tourism }\end{array}$ & $\begin{array}{l}\text { Prace Studium } \\
\text { Turyzmu UJ }\end{array}$ \\
\hline & $\begin{array}{l}\text { Wanda } \\
\text { Leszczycka }\end{array}$ & $\begin{array}{l}\text { Wytyczne polityki turystycznej } \\
\text { w Szwajcarii }\end{array}$ & $\begin{array}{l}\text { The tourism policy } \\
\text { in Switzerland }\end{array}$ & Tourism of Poland \\
\hline & $\begin{array}{l}\text { Angelo } \\
\text { Mariotti }\end{array}$ & $\begin{array}{l}\text { L'organizzazione turistica } \\
\text { nell'Italia }\end{array}$ & $\begin{array}{l}\text { The organization } \\
\text { of tourism in Italy }\end{array}$ & Tourism of Poland \\
\hline
\end{tabular}


Table 3. Continued.

\begin{tabular}{lllll}
\hline Year & Author & Original title & English title & Journal \\
\hline 1939 & $\begin{array}{l}\text { Wiktor } \\
\text { Ormicki }\end{array}$ & $\begin{array}{l}\text { Podstawy gospodarki } \\
\text { turystycznej we Włoszech }\end{array}$ & $\begin{array}{l}\text { The basics of the tourism } \\
\text { economy in Italy }\end{array}$ & Tourism of Poland \\
& $\begin{array}{l}\text { Zbigniew } \\
\text { Tokarski }\end{array}$ & $\begin{array}{l}\text { Zagospodarowanie } \\
\text { turystyczne Karpat' }\end{array}$ & $\begin{array}{l}\text { Tourism facilities of the } \\
\text { Carpathians }\end{array}$ & Tourism of Poland \\
& Karlis & Fremdenverkehrs in Lettland & Tourism in Latvia & Tourism of Poland \\
Vanags & & & \\
\hline
\end{tabular}

Tourism and its graduates also significantly contributed to the development of regional and spatial planning. All of the school's studies were characterized by very detailed statistical documentation. Monographic regional studies, e.g., on the issues of tourism and health resorts in Podhale (being examples of mountain areas) and in Silesia (in relation to industrial areas) had great methodological value. The school's achievements in tourist cartography, especially the works related to the Tourist Atlas of Poland, are also noteworthy. The school intensively cooperated with similar government and local government institutions, research centers, and tourist organizations in Europe. The Jagiellonian University School of Tourism's activities helped raise awareness in society of the importance of the place of tourism in the socio-economic development of regions and cities.

Owing to the activities of the school, Krakow led the Polish tourism geography for many years. Educated in the interwar period, the "Krakow School" significantly developed in the post-war years. In the 1970s and 1980s, the school's studies were continued by the Institute of Geography at the Jagiellonian University, now the Institute of Geography and Spatial Management. The actions of the Jagiellonian University School of Tourism were also taken over by other geographical centers in Poland associated with the universities in Łódź, Wroclaw, and Warsaw, and the Institute of Geography at the Polish Academy of Sciences.

Today, tourism education is highly developed, and it is found in most institutions of higher education in the world (Airey, 1979, 1994, 2011; Cooper and Westlake, 1989; Xiao, 1999; Maclaurin, 2005; Pearce, 2005; Reichel, 2005; Weiermair and Bieger, 2005). The achievements in tourism education and research of such units as the Jagiellonian University School of Tourism make this discipline still play an important role among all other sciences dealing with tourism.

Competing interests. The authors declare that they have no conflict of interest.
Acknowledgements. We would like to thank two anonymous reviewers and editor Giovanni P. Gregori for the helpful comments and corrections that have substantially improved the earlier version of this paper.

The publication was co-financed by the PhD Candidates' Society of the Jagiellonian University.

Edited by: G. P. Gregori

Reviewed by: two anonymous referees

\section{References}

Airey, D.: Tourism education in the United Kingdom, Revue de Tourisme, 2, 13-15, 1979.

Airey, D.: Education for tourism in Poland: The Phare programme, Tourism Manage., 15, 467-471, doi:10.1016/02615177(94)90068-X, 1994.

Airey, D.: United Kingdom, in: An International Handbook of Tourism Education, edited by: Airey, D. and Tribe, J., Routledge, London, New York, http://lib.dtc.ac.th/ebook/Tourism/ An-International-Handbook-of-Tourism-Education.pdf (last access: November 2016), 271-284, 2011.

Blanchard, R.: Grenoble, Étude de géographie urbaine, A. Colin, Paris, 1911.

Blanchard, R.: Nice et les Alpes maritimes, Esquisse économique, Les Alpes économiques, 6, 109-119, 1919.

Blanchard, R.: Le tourisme dans l'Isère, Grenoble et sa region, Allier, Grenoble, 1925.

Blanchard, R.: Les Alpes françaises à vol d'oiseau, Arthaud, Grenoble, 1928.

Cooper, C. and Westlake, J.: Tourism education of Western Europe, Tourism Manage., 10, 69-73, doi:10.1016/0261-5177(89)90037X, 1989.

Grünthal, A.: Probleme der Fremdenverkehrsgeographie, Foschungsinst. für den Fremdenverkehr, Berlin, 1934.

Hasser, K.: Die Städte geographisch betrachtet, B. G. Teubner, Leipzig, 1908.

Hettner, A.: Die Geographie, ihre Geschichte, ihr Wesen und ihre Methoden, Ferdinand Hirt, Wroclaw, 1927.

Jackowski, A.: Rola Studium Turyzmu Uniwersytetu Jagiellońskiego w rozwoju badań naukowych w dziedzinie turystyki w Polsce - The role of the Jagiellonian University School of Tourism in the development of scientific research in the field of tourism in Poland, in: Współczesne uwarunkowania i problemy 
rozwoju turystyki, edited by: Pawlusinski, R., Institute of Geography and Spatial Management of the Jagiellonian University, Krakow, 47-59, 2003.

Jackowski, A.: The contribution of geography to the development of tourism research in Poland, Tourism, 20, 5-36, doi:10.2478/v10106-010-0006-9, 2010

Jackowski, A. and Liro, J.: Studium Turyzmu Uniwersytetu Jagiellońskiego (1936-1939) - The Jagiellonian University School of Tourism (1936-1939), in: Turystyka i rekreacja jako przedmiot badań geograficznych, edited by: Młynarczyk, Z. and Zajadacz, A., Adam Mickiewicz University, Poznań, 9-22, http://turystyka. amu.edu.pl/tomy/tir14.pdf (last access: November 2016), 2015.

Jackowski, A. and Sołjan, I.: Z dziejów geografii na Uniwersytecie Jagiellońskim (XV-XXI wiek) - The history of geography at the Jagiellonian University (15th-21st centuries), Krakow Institute of Geography and Spatial Management of the Jagiellonian University, Krakow, 2009.

Klimaszewski, M.: Studium Turyzmu U. J. - The Jagiellonian University School of Tourism, Wierchy, 14, 210, 1936.

Kohl, J. G.: Der Verkehr und die Ansiedelungen der Menschen in ihrer Abhängigkeit von der Gestaltung der Erdoberfläche, Arnold, Dresden, 1841.

Lasserre, P.: Lourdes-études géographiques, Revue géographique des Pyrénées et du Sud-Ouest, 1, 5-40, 1930.

Leszczycki, S.: Sprawozdanie z działalności Studium Turyzmu U.J. za okres 1.V.1936-30.IX.1937 - A report on the activities of the Jagiellonian University School of Tourism for the period 1.V.1936-30.IX.1937], Komunikaty Studium Turyzmu UJ., 1, 1937.

Leszczycki, S.: Współczesne zagadnienia turyzmu - Contemporary issues of tourism, Komunikaty Studium Turyzmu UJ., 3, 1938.

Leszczycki, S.: Geneza i powstanie Studium Turyzmu na Uniwersytecie Jagiellońskim w Krakowie' - The origins and the foundation of the School of Tourism at the Jagiellonian University in Krakow, Prace Geograficzne, 89, 9-37, 1992.

Maclaurin, D.: Tourism Education in Canada, J. Teach. Travel Tourism, 5, 1-25, doi:10.1300/J172v05n01_01, 2005.

Mariotti, A.: Corso di Economia Turistica, Instituto Geografico de Agostini, Roma, 1933.

Mariotti, A.: L'organizzazione turistica Nell'Italia, Komunikaty Studium Turyzmu UJ, 17, 27, 1939.
Mitchell, L. S. and Murphy, P. E.: Geography and tourism, Ann. Tourism Res., 18, 57-70, doi:10.1016/0160-7383(91)90039-E, 1991.

Nawratilówna, E.: Studium Turyzmu na Uniwersytecie Jagiellońskim - The School of Tourism at the Jagiellonian University, Z bliska i Z daleka, 6, 140-143, 1938.

Norval, A. J.: The tourist industry: a national and international survey, Sir Isaac Pitman \& Sons, London, 1936.

Ogilvie, F. G.: The tourist movement. An economic study, P. S. King \& Son, London, 1933.

Panosso Nettoa, A. and Jäger, M.: Robert Glücksmann (1877_ 1942): founder of Berlin School of Tourism Research, Anatolia, 26, 1-10, doi:10.1080/13032917.2015.1099089, 2015.

Pearce, P. L.: Australian Tourism Education, J. Teach. Travel Tourism, 5, 251-267, doi:10.1300/J172v05n03_04, 2005.

Poser, H.: Geographische Studien über den Fremdenverkehr im Riesengebirge, Vandenhoech, Göttingen, 1939.

Ratzel, F.: Anthropogeographie Grunzüge oder der Anwendung der Erdkunde auf die Geschichte, J. Engelhorn, Stuttgart, 1882.

Reichel, A.: Tourism and Hospitality Higher Education in Israel, J. Teach. Travel Tourism, 5, 61-88, doi:10.1300/J172v05n01_04, 2005.

Ritter, K.: Die Erdkunde them Verhältnisse zur Natur und zur Geschichte der Menschen, G. Reimer, Berlin, 1822-1859.

Stadner, J.: Der Fremdenverkehr, Leykam, Graz, 1905.

Tokarski, Z.: Wydawnictwa Studium Turyzmu Uniwersytetu Jagiellońskiego w Krakowie - Publications of the Jagiellonian University School of Tourism in Krakow, Prace Geograficzne, 89, 6187, 1992.

Vidal de la Blache, P.: Principes de géographie humaine, A. Colin, Paris, 1922.

Wegener, G.: Der Fremdenverkehr in geographischer Betrachtung, Georg Stilke, Berlin, 1929.

Weiermair, K. and Bieger, T.: Tourism Education in Austria and Switzerland, J. Teach. Travel Tourism, 5, 39-60, doi:10.1300/J172v05n01_03, 2005.

Xiao, H.: Tourism education in China: Past and present, Asia Pacif. J. Tourism Res., 4, 68-72, doi:10.1080/10941669908722046, 1999. 